\section{Ethical Lingua}

Journal of Language Teaching and Literature

ISSN 2355-3448 (Print)

ISSN 2540-9190 (Online)

Volume 6, Number 2, August 2019

pp. $45-58$

\title{
The Short Story "I Want My Son to Become a Murderer" in Deconstructive Analysis
}

\begin{abstract}
Siti Hafsah
siti.hafsah@uniba-bpn.ac.id

Universitas Balikpapan, Indonesia

Received : 10 December 2018; Accepted: 26 June 2019

DOI : https://doi.org/10.30605/25409190.v6.45-58

Abstract

Deconstruction in short story "I Want My Son to Become a Murderer" shows a binary opposition which leads into an understanding that there is no hierarchy opposition. Derrida deconstruction in literary work aims to show logical and rhetorical non-equivalence between what explicitly written and what is implicitly hidden in the text. The deconstruction study shows how the contradictions should be uncovered from the text which called dissemination. The result of the analysis shows the opposition found are: (1) opposition between title and story; (2) opposition between the story and the footnote; (3) opposition between intuitive comprehension and logical reasoning; (4) opposition between fact and fiction; (5) opposition between "I lyric" and many people; and (6) opposition between the writer and the reader.
\end{abstract}

Keywords: deconstruction, dissemination, binary opposition 
Hafsah:

The Short Story "I Want My Son to Become a Murderer" in Deconstructive Analysis

\section{Introduction}

Whani Darmawan's short story in anthology I Want My Son to Become a Murderer (IWSBM) discussed by Marshall Alexander Clark seems different from other works. In preface, Marshall states that Whani is a newcomer in Indonesian literature field, yet, her reputation grows bigger. Whani was born in Yoggyakarta at the beginning of new order. With the assistance and advice from other senior writers in Jogjakarta, such as from poet and humanist Emha Ainun Nadjib, at the early 1980 Whani started writing poem, essay, and short stories. Her debut almost in the same period with young writer Agus Noor and Indra Tranggono. In play, she followed her predecessor; Landung Simatupang and Butet Kartaredjasa. In 1990, Whani learns and put more attentions to literature field and become a writer. She also becomes a play scriptwriter and director from few plays performance. One of them was performed in 1998. Among many of the cultural performance to describe the resignation of Soeharto, is Karno Tanding written by Whani which stood out over others. The plays that explore body power as a speaking media and covered with tense atmosphere has attracted attention from Indonesian and foreign critics. Whani's implicitly uttered that her play does not only tell a story about Ksatria Kurawa from Javanese puppet shows, Karno, but also a story about Indonesian contemporary sociopolitical condition. Even one of the Bernas reporter as "What does the director perform in this play?"

The curiosity is also faced by readers who read the first Whani's short story anthology, IWSBM. With typical Indonesian language, full of irony and poetic nuance. Not all short stories have a usual plot as if it has its own life, free from the authors' force. "I Want My Son to Become a Murderer" is a short story that also as a book title that consists of 16 short stories (1999). They are Penggal Kodrat Alam; Tenggara; Perjaka Tua; Air Cucuran Atap; Merpati Persi; Istriku yang Terkasih; Waniti Naga; Lampor; Lelaki Pembakar Sampah; Burung - Burung Putih (Bernas period 1989 - 2000). Penang Karang Binatang (Prosa Journal, Vol. 1. March, 2002), Larung; Setangkai Dahan Kering (Original 2000 - 2001); Mak Gerabik (Suara Merdeka, 2001) Penyakit (Pikiran Rakyat, 1994), Kabesmen (Basis, 1997). Other than IWSBM, other anthologies are Rembulan Padhang Ing Ngayogyakarta (1992), Penglion (1994), Guru Tarno (1994), Embun Tajali (2000), Shadow - Boxing = The Wayang and Modern Indonesia Literature (Dissertation Marshall Clark, 1998), and many others Whani Darmawan works.

Thus, the short story "I Want My Son to Become a Murderer" (IWSBM) has a very fundamental reason for writer to make it as the object of this research. Apart from the title which invites readers' curiosity and reaction, it will trigger more reaction after reading it. Another thing of this short story is the plot, which follows the post-mo tradition. 
Researcher chooses IWSBM out of other short stories in the antology book, to be able to provide a detail and focus analysis, both of these aspects is a soles rapture and become a major attention in deconstruction analysis (Eagleton, 1983:33).

\section{IWSBM Synopsis.}

A man named Karta, wants his son to become a murderer, he has determined to achieved that, he will do whatever it takes to make it comes true. He thinks that his son must become who always stand for his rights, never give up, and even have to murder to meet his needs. Since birth, his son was named Tunggal Pamenang Jagad, and has met his first wish where Tunggal's mother passed away during giving birth to Tunggal. Therefore, the first one Tunggal murdered is his mother, and Tunggal was then raised based on his own way, forcefully raised. Whenever Tunggal needed breastfeeding, he was given cow milk. Karta will push Tunggal below the cow and dring the cow milk till it skinny. That's how Karta raises his son which according to people around, he is considered insane.

Tunggal then grows fast, his body is big twie as other boys on his age. Karta's expectation grows bigger to make his sin become a murderer. One day his son murders his mother in law, which is Tunggal's grandmother, just because a petty reason, that the grandma suggest that Tunggal was given a sajen (traditional offerings to the spirit) so he will grows normally. With that murderer, Karta is so happy because his wish has come true, Tunggal becomes murderer. It also means that two people has been murdered, the first is the mother and then the grandmother.

But then unexpectedly his wish does not come true, when the boy murders the father in law by beheading him, then suddenly he swings to him, as if the meaning is clear that the next one to kill by Tunggal is his own father, who has taught him to become a murderer.

How surprise Karta is, that his ambition to make his son as a murderer has come true, but his son then have to murder him. At the end, Karta says "I never expect that he will murder me! Something stupid that should be taught by all parents". That is the last words form Karta before he is murdered by his own son.

\section{Method}

As an analysis method, deconstruction usually starts with the analysis to identify the binary opposition in a text, then reversing it or show the contradictions in a text that disguise the hierarchy or the boundary between the two, a general method in deconstruction to see the rhetorical strategy in a text, and using it to "interrogate" the text itself (Budianta, 2002).

The binary opposition conducted two different things which may appears to explain each other. Such thing that can demonstrate an illustration of binary 
Hafsah:

The Short Story "I Want My Son to Become a Murderer" in Deconstructive Analysis

opposition are dark and light, up and down, day and night. Derrida in Tyson (2006) stated that :

One must examine the ways in which the two members of the opposition are not completely opposite, the ways in which they overlap or share some things in common (Tyson, p. 254).

This quotation demonstrates that even though the contradiction appears as two different things, it still may explain each other and correlate to each other meaning. Derrida in Yegen \& Abukan also argued that binary opposition or pair in which one part of that pair is always more important than the other such as the superior is "marked" as positive and the inferior as negative (Yegen \& Abukan, 2014).

Derrida's method in text reading is known as Metaphoric. This metaphor is not an aspect of language expressive function, but as a essential condition about an utterance (Sarup, 1993:47). Metaphor represents one way to arrange discourse and strongly affect how we understand may things ( (Sarup, 1993:48). Thus, the deconstructed text is a text written by writers which metaphor on it self. Deconstructtion is a careful text reading, by interrogating text, destroy it towards it defense, dan find the binary position written in the text (Samp, 1993:50). It also states that deconstruction starts from metaphysical binary opposition (Choi, 1998:5).

The analysis through a deconstruction theory appear in many ways such as using a binary opposition which conduct an antilogy, since analyzing a text or meaning can overcome multiform contentions. Carter stated in his book about Derrida's theory that all texts, whether it is literary or not can be deconstructed. It may appear as dismantling the texts or only part of them, reveal the inconsistencies in them (the texts) and even though the texts seems to imply one thing it can be imply the opposite of it (Carter, 2006, p.111). In this step, writer/reader or reader/writer try to provide an opposition and/or a contradiction in a text.

Deconstruction put more attention in metaphor and can not be broken down into smaller part which become a different thing in a game of literal rules. Deconstruction is not a reversing make up strategy, it is an activity of reading in a new radical way. There must be an awareness of two opposites feeling, about non-equivalence between meaning and writers explicit statement. (Sarup, 1993:51-52).

Barbara Johnson explains that the concept " difference" appeared from a text is not something that differentiates one identity to another, not the difference among (several independent units) but "The internal difference" (Young via Melani 2002). "Far from constituting the text's unique identity, it is that which subverts the very idea of identity, infinitely differing the possibility of adding up the 
sum of a text's part or meaning and reaching a totalized, integrated whole (Young, 166)"

Furthermore, a text with deconstructive reading has passed beyond itself, the referent at the end can be another text. As a sign eventually refers to other text, the cause of the crossing and network than can be developed time after time, intertextuality (Satrup, 1993:52).

On the practical level, deconstruction covers reversing and transferring (Sarup, 1993:51). In order to destroy the reversing hierarchy opposition. In the next phase, this reversing should be transferred, the particular terms is placed under the deletion (sous rature). The text in border can be revealed.

\section{Results \& Discussion}

\section{Deconstructive Reading to IWSBM}

First, in this deconstructive reading, "IWSBM" short stories are considered a metaphor. Inside, the language works from one type of reality to another reality (Sarup, 1993:47). This reality which uttered internally contradicts from one to another. This contradiction is then called the binary opposition. Although in deconstruction context, the binary opposition as always in hierarchy, but the deconstructive reading tries to destroy the hierarchy and return is as writing, as it is conducted in deconstructive reading of "IWSBM"

During deconstruction reading conducted by researcher to the "IWSBM" short stories, researcher finds binary opposition (1) Opposition between title and the story;(2) Opposition between the story and footnote; (3) opposition between logical think and intuitive comprehension; (4) opposition between fact and fiction; (5) Opposition between "I" lyric and them; (6) Opposition between writer and reader

\section{Opposition Between Title and the Story}

Although the short story "IWSBM" seems has no plot as a post-mo tradition, its title has been a deconstruction of a condition which contains a continuous meaning. Not stop only at the title, it even invites variety of questions and will end up an uncertain or ambiguous answer, for example: what is written in the story IWSBM "Mereka menuduhku gila" [They think that I am insane] (p.14).

In another perspective, IWSBM is a structure, that seems has a center. The title can be said as a center because : (1) The position is written with a particular space and even can be seen separate from the story, with less number of letters; (2) Written in a separate front page; (3) Written with a capital letter; (4) is a primary point of the story.

Whereas for the story itself, the position different from the title, even in "IWSBM" the position is separate from the pages, but it can ensure that in a 
Hafsah:

The Short Story "I Want My Son to Become a Murderer" in Deconstructive Analysis

hierarchy, it is a subordinate of the title. The story "IWSBM" is the description of the title, even a broader development of the title. Therefore, clearly appears that it is structurally correct. Nonetheless, post-structurally it is not correct, because the relation between the two is not opposition but as a hierarchy. It can be stated that the title is named title because there is a story, more precisely, if there is no story, then the row of words will not be called as a title and vice versa.

Therefore, the story without a title can still become a story, then what is left is a story; the title still exists but become sous rapture. Thus, it can be stated that in this reading context, the story IWSBM is more dominant. Thus there is no center to position the title.

There is only a condition that deconstructive reading does not mean to drop one of them, but only to return that everything is only a text, even though the story appears more dominant, but in reality, is not. Because the story needs to be metaphorized to be able to comprehend easily, this is done by assigning a title. With that point, the title is considered important, because the title contains a story and vice versa. Because the interpretation of the two is interdependence.

\section{Opposition Between the Story and Footnote}

As discussed, that a title and a story can no longer be separated, because both are also text, and the next step will use the word "story" to refer to above which is a footnote. Similar to the relationship between title and story, relation between 'story' and 'footnote" appear structurally and also shows the opposition, hierarchy relation.Story is the main description because it is written in the upper part, with a bigger font. The story is things that the author wants to describe, thus, the position is separate from the footnote.

As an additional note that describes a story for a particular point or unit in a story, then the footnote is provided. Because it is only additional, then it is written in the lower part with a smaller font. Thus, as an additional, the footnote can be provided, but can also be omitted. It means that even the footnote is not provided, the readers will still be able to understand the story. Readers can understand the "IWSBM" without reading its footnote. From structuralism perspective, it is true, but according to post-structuralism, it is not true.By answering the question, the data and relation built in the story and the footnote should be stated. For example, researcher quotes relation between the story and the footnote (1)

...Anak itu masih bayi. la belum bisa dimandikan dengan air dingin. Tubuhnya harus digedong ${ }^{1}$ agar kakinya lurus. Kalau magrib harus dipangku². Pipinya jangan kau cubiti, karena itu milik pamongnya ${ }^{3}$.... Berikan padanya jenang abang, jenang putih, jenang berok ${ }^{4}$, supaya tidurnya tenang. Kalau suatu saat ia cegukan, biarkan. Pertanda ia akan dewasa ${ }^{5}$. (Hal 14) 
[.. The boy is still a baby. Can not be bathed with cold water. His body should be swaddled so he will have a straight leg. In the afternoon he must sit on lap. Don't pinch his cheek, because it belongs to his nanny. Give him red jenang, white jenang and jenang berok (a Javanese traditional snack made of glutinous rice with brown sugar and coconut) ...., so he can sleep calmly. One day if he has hiccup, let him. It means he will grow up 5 (p. 14)]

The quotation above shows phrase, .... Triggers the footnote, and to clear the explanation from footnote 1 the explanation is described as below :

1. Swaddle = To put a baby in a blanket, and cover him from leg to head, to keep him warm

2. Sit on lap $=$ To put the baby on parents lap

3. Nanny= The one who babysits the baby

4. Breastfeeding $=$ to give baby breastfeed

5. red jenang, white jenang and jenang berok = traditional Javanese porridge for ritual

6. Clove: a type of spices, (p.14).

Another quotation as described in the story "IWSBM" can be seen from the next quotation :

...aku tahu secara teori bay harus diberi ASI, tapi karena dia telah membunuh ibu nya, biarlah ia kukempongkan..(hal. 15)

[...l know theoretically a baby should be breastfed, but because he has murdered his mother, let me give him pacifier 7 ...(p. 15)]

... Mertuaku meminta kepadaku untuk member sesaji kepada anakku. Alasanya karena sejak lahir Tunggal tidak diberi sesaji. Tidak ada sesaji mitung dinani ${ }^{8}$, tidak ada sesaji nyelapanan ${ }^{9}$, karena hal itulah mertuaku untuk menyuruhku untuk meruwat ${ }^{10}$ anakku.

[My mother in law asked me to give offering to spirits for my son. The reason is since he was born, Tunggal hasn't been given any. There is no offering to spirits for seven days, there is no for thirty days, that $s$ why my mother in law asked me to hold traditional ritual for my son's blessings.]

From the quotation above, there are phrases to describe with a footnote, which is....

8. seven days : ritual for baby after seven days of birth

9. 30 days: ritual for baby after 30 days of birth

10. Traditional ritual for blessings: to pray for his blessed life (hal. 17)

It is then continue with the next description as below :

...Kalau tidak diruwat, terus bagaimana aku ini? Aku kan tidak enak dengan tetangga kanan kiri. Terus bagaimana dengan projoku? Coba pikie, projokuuu!" (Hal.10)

[..If you don't hold any traditional ritual for his blessings, then what am I supposed to do? I feel bad to the neighbours. Then how with my image? Think about that, my image!! (p. 10)] 
Hafsah:

The Short Story "I Want My Son to Become a Murderer" in Deconstructive Analysis

Image: self-image (p.18)

From the quotations above, it is clear that what written in a footnote $-I$ and the footnote is not to describe each other. Thus, between the footnote $-I$ and its description is not dependable to each other. It can stand on its own; even it can be a writing that has a longer explanation. It is also true with footnote - I or the story can still happen without a footnote. Thus, the relation between the two is not in hierarchy opposition. The relation is like a story, describe that the short story does not really depend on place, font size, and all the things that show the relation of hierarchy opposition. The relation is equal, not hierarchial.

\section{Opposition Between Logical Reasoning and Intuitive Comprehension.}

In "IWSBM" as described earlier in this writing, apart from the title "I Want my Son become a Murderer". Implicitly, the author has set an inner experience of the 'I " character, which has deconstructed the logical explanation but indirectly has destroyed the opposition by returning the action of the object to the subject. In this case, there is no center, even it has altogether returned as a text which the writer herself return the experience trough language. In the language there is no hierarchical opposition; what exists is the meaning that appears from the disparity and the meaning of a symbol that never perfect. It means as language construction, between intuitive comprehension and reasoning are both texts. In this case, can be seen from the example below :

"...Aku merindukan anakku menjadi pembunuh. Inilah cita - cita besar yang membanggakan dalam hidupku. Biarlah aku dituduh menjadi sipir penjara emas bagi anakku. Biarlah aku dituduh memboneka anakku" (hal.12)

["... wish my son become a murderer. This is my big ambition that can make my life proud. Let them think that I am an inmate guard in a golden jail of my son. Let them think that I am the muster of puppet of my son " (p. 12)]

\section{“...Aku rindu anakku jadi pembunuh! Apapun akan kulakukan demi cita - cita itu” (hal.15) \\ [". I wish my son become a murderer! I will do whatever it takes to achieve that" (p. 15)]}

From quotation above, it appears that an internal experience which grows in the "l" character which intuitively has the power to achieve an illogical wish. Whereas what the author set as logical reasoning even needs that power, thus, there is no hierarchical opposition occurs.

“...Aku tidak akan pernah mengizinkan ada guru dalam hidupku. Kalau kau menjadikan aku sebagai pembunuh, maka aku merindukan membunuhmu. Aku harus memutuskan pertalian darah dan batin ini dengan berani. Kalau yang prinsip ini tak aku lakukan, maka kau tak akan dapat menyaksikan diriku seperti engkau harapkan. Maaf, dengan ikhlas dan berani aku harus membuhmu." 
[". I never let any teacher in my life. If you make me become a murderer, then I wish I could murder you. I have to cut our family relationship bravely...If I don't do this principal thing, then you will never see me as the son you are expecting. Sorry, but bravely and sincerely I have to kill you."]

“... ia telah meleset menjadi pembunuh seperti harapan ku ... tetapi aku tidak menyangka kalau ia akan membunuhku! (hal. 19).

["..he has not become a murderer as I expect...but I never imagine that he will murder me! (P. 19).]

What is discussed above is a contradiction that seems to be represented by one word "murderer" which has a specific ambiguous meaning that is put as a difference which means that the difference comes from the meaning, whereas the meaning itself is never perfect. Therefore, it returns to both things between logical reasoning and intuitive comprehension both become text.

\section{Opposition Between Fiction and Fact}

The opposition between fiction and fact has appeared in relationship between "Story and footnote (the $1^{\text {st }}, 3^{\text {rd }}, 8^{\text {th }}, 9^{\text {th }}, 10^{\text {th }}$ ). The first one, it similar but still given words swaddle, whereas swaddle in a footnote as a fact, and the explanation that it has a fiction and fact meaning (P. 14). The same is also true for the $5^{\text {th }}$ where appears the word jenang (a Javanese traditional snack made of glutinous rice with brown sugar and coconut) as a fact that all types of ritual porridge, whereas in fiction, he is given those porridges to make him sleep calmly (p.14). Furthermore, in the $8^{\text {th }}$, the seven days ritual is a fact to hold a seven days after birth ceremony, whereas in the text "the reason is that since he was bornm he has not been given any offering for spirits, there is no seven days rituals ...(p.17). Then in the $9^{\text {th }}$ as a fact for 30 days rituals, means thirty, is same with the fiction which is to conduct the 30 days after birth ceremony (p.17), and the $10^{\text {th }}$ as a fact to hold a ritual for blessing, whereas, in the fiction, it must be done for a baby. Otherwise he will feel inconvenient with the neighbors. (p.17).

Other from what discussed above, in "IWSBM" is also appears an opposition between fact and fiction.

"Aku merindukan anakku menjadi pembunuh! Apapun akan kulakukan demi cita - cita itu. Aku tahu! Menurut teori bayi harus mendapatkan ASI, tapi karena ibunya sudah dibunuhnya, biarlah ia kukempongkan pada ASSI; Air Susu Sapi. (hal. 15)

[". I wish my son become a murderer! I will do whatever it takes to achieve that I know theoretically a baby should be breastfed, but because he has murdered his mother, let me 
Hafsah:

The Short Story "I Want My Son to Become a Murderer" in Deconstructive Analysis

give him breastfed by a cow (p.15)]

The quotation above shows a fact in a story from the acronym ASI (Mother's breast milk) and is constructed become ASSI (cow's breast milk) as a fact the author sets that. At the same time also, behind the word ASSI is put in a fiction condition, thus it becomes fact to what contains in the word ASSI, ASSI is merely the text which has no hierarchical opposition between the two.

“...Maka kalau anakku berteriak haus, segera kusorongkan ia ke bawah perut sapi diantara kangkangan empat kaki, bergantungan diantara puting susu dan glambir daging. la sedot...... Hingga sapi itu kempes..... Anakku tumbuh oleh ASSI." (Hal 16)

["..Then when my son shouts for thirsty, I will push him under the cow's belly, between the cow's leg, hanging among the cow's f;esh and nipple. He will suck the milk, till it dry..my son is grown up with ASSI (cows' breast milk) (p.16)]

It seems that the word $A S /$ is then extended to the word $A S S I$, which stand for cow's breast milk. As a fact that this milk is commonly consumed by the baby nowadays. Thus, what appears inside is a satire that nowadays what baby consume is no longer mothers breast milk, but cow's breast milk. What contains in the "IWSBM" short story position the cows' breast milk as an opposition of fact and fiction, but because only that one word, it is a meaning from an imperfect symbol, thus the hierarchical opposition is destroyed by it.

\section{The Opposition Between the "I" lyric and the People.}

In "IWSBM", this opposition means someone who owns the story which is "I" lyric compared to many people. This opposition relates to the characters in the story. In one hand, it is described that "I" is the center whereas on the other side, "People" is only a peripheral character.

"Aku merindukan anakku menjadi pembunuh......aku benci pada orang yang menyembunyikan kebanggannya dalam sarung kemunafikan....kenapa orang takut otoriter?.....

Aku tidak menginginkan kebesaran anakku lahir istimewa melalui mulut orang tua yang narcis dan dungu....

Aku ingin menggembleng anakku sekeras baja...." (hal 12)

["I wish my son to become a murderer... I hate people who hide their proud in the cover of hypocrisy... why do people afraid of authoritarian?

I don't want the great of my son who was born special trough the mouth of his dumb parents...

I want to force my son to be as strong as steel" (p.12)]

Aku merindukan anakku menjadi pembunuh! Apapun akan kulakukan demi cita - citaku itu......, Aku, tahu menurut teori bayi harus mendapatkan ASI....." (hal 15) 
[". I wish my son become murderer! I will do whatever it takes to achieve that I know theoretically a baby should be breastfeeded.." (p.15)]

... Aku bangga! Aku hidup!....., Aku tak ingin anakku menaruh kasihan kepada siapapun , ....., Aku tak ingin mengajarkan anakku pada kemengalahan pokoknya percuma ia menjadi anakku ...... Kalau haruslah orang yang berkhasrat!!! (hal 17) Aku bisa menyaksikan cita citaku terkabul! (hal 18).

[... I am proud! I live! I don't want my son to feel sorry for anyone... I don't want to teach my son to give up... The point is he is useless to be my son...if other people has what they want from him!! (p.17). I can watch my wish comes true! (p.18)]

What described above shows the power of "I" on how he wants to control others include his son whom he considers as a property, his property without further consideration that one day his son will be grown up as him. It seems that the author put him as a character who has control over everything, as "I" acts as the center, knows everything without anyone can argue and stand on his way. Nevertheless, on the other side, the author reverses the situation where the people replace the "I" position.

"Para tetangga yang menyasikan caraku mengemban anakku tidak terima. Mereka menuduhkan gila.....

"Kau tidak bisa begitu Karta!" seru salah satu antara mereka "Anak itu masih bayi! ....... Kalau maghrib harus ......, pipinya jangan kau cubiti ....., kalau suatu saat cegukan ..... biarkan .... jangan keluar malam ....... ....., III.... Ini malah kau celupkan ke air tebar keparat! Bagaimana kamu ini, lelaki memang tak bisa momong bayi, lebih baik kau titipkan ke panti asuhan, mertuamu, atau siapa saja perempuan yang mau ..... menjadi pengasuhnya ..... awas! Jangan lupa kau berserisir tiap hari kalau ....." (hal 13, 14, 15)

[The neighbours who see me raise my son do not accept it, They think I am insane...

"You cant do that Karta!"..says one of them.."The boy is still a baby!..during end of day...don't pinch his cheek..if he has a hiccup ...let him...do not go out during night...you even put him into a water, bastard!. How could you do that, as usual, a man ca not baby sit a baby..you better put him in orphanage home, or to your parents in law or any other woman who wants to raise him... watch out! You should brush him everyday if... $(p .13,14,15)$

Quotations above is a contradiction which destroyed what is called as center and peripheral. Because in this case, there is no hierarchical opposition, the center even switches to become peripheral and vice versa, as seen where "the people" turn to correct and order the "I" which is significantly has more control and in turns, has become under control.

"Aku bisa menyaksikan cita - citaku terkabul! Tetapi belum lagi habis rasa banggaku, tiba tiba anakku berbalik menghadapi tubuhku. Dipandangnya aku seolah - olah bapaknya ini cuma makanan kecil yang siap ia telan melintang .... Anakku berkata ..... "Aku tidak akan 
Hafsah:

The Short Story "I Want My Son to Become a Murderer" in Deconstructive Analysis

pernah mengijinkan ada guru dalam hidupku ..... kalau kau menjadikan aku sebagai pembunuh, maka akan merindukan membunuhmu ..... aku harus memutuskan pertalian darah dan batin ini dengan berani. Kalau yang prinsip ini tak aku lakukan, maka kau tak akan dapat menyaksikan diriku seperti yang engakau harapkan. Maaf, dengan iklas dan berani membunuhmu." (hal 18, 19)

["I can watch my wish comes true! But as my proud has not ended yet, suddenly my son return to fight against me. He sees me as if I am only a little snack that ready to be swallowed..my son says..." ".. I never let any teacher in my life. If you make me become a murderer, then I wish I could murder you. I have to cut our family relationship bravely...If I don't do this principal thing, then you will never see me as the son you are expecting. Sorry, but bravely and sincerely I have to kill you." $(p .18,19)]$

Descriptions above provide a sufficient explanation that the author is knowledgeable in arranging the firm binary opposition and then destroy it, and reversing both oppositions, thus, we will easily capture the understanding of the twisted meaning as previous one, where there is no center and peripheral, what exist in both is text.

What is more important is the things that we uncover from inside is the trace which can be seen as a left satire.

"la telah melesat menjadi pembunuh seperti harapanku. Tetapi aku tak menyangka kalau ia akan mebunuhku! Sesuatu yang bodoh mustinya bisa, boleh dan harus di pikirkan oleh setiap orang tua." (hal 19).

[..he has not become a murderer as I expect...but I never imagine that he will murder $m e ! "(p .19)]$

From the quotation above, we can precisely relate that with a saying that commonly heard, become boomerang, that who throws away a bad thing will return to him, it can also mean, the son exists because the parents do. The son who was as "people" or part of it, has become the "I" that replaces the position of his father, thus, it is very important the existence of the son and so is the parents in capacity of the other.

\section{Oppositon Between the Author and the Reader.}

In "IWSBM", a short story which is written by the author undoubtedly with an intended purpose, whether to criticize a social condition or to express his subjective experience, to express his idea trough the works or merely wants to write. What is clear is after we read "IWSBM", it comes with its unique story, even from its title which makes us wonder and curious, how could things like that happen? "I want my son to become a murderer: but the appearance of the "IWSBM" clearly comes from one party only, which is the author.

It starts from the writing process, then sending it to a media and then is published to be a short story anthology by a publisher, then reach the readers, 
and has to accept the short story as it is, and can not change it. It seems that this context, the author and the reader has a hierarchical opposition. Because the author is the ordinate and the reader is the subordinate.

It does not go that way, only in a glance seems as it is, but with further examination, it does not. In reading, reader has a unit of imagination experience, past, life romanticism, and all other experiences that differ from the author's experience. With those experience factors, it affects the readers in reading the short story "IWSBM". Thus, it is possible that the reader understanding from one to another will be different. In this context, what is a=true is she also writes. That will appear clearly if the readers become a writer.

Then there will be a change of role from the reader to an author which shows that the has been the process of elimination of center, initially, the center is the author, but then, the readers also become the writer. Then what is left is only writer. Then conclusion is drawn that in the writing process there is a reading process. From the explanation above, it appears that hierarchical opposition is only an illusion because the writings above are only the chain of signifiers. Where the signified is basically a signifier, each signifier has never had a perfect meaning because half of its meaning has embedded on the other signifiers, that even in unlimited amount. The relation between those signifiers has resulted what is called as text.

Then, as a text, the short story "IWSBM" is a chain of signifiers that form a particular signifier unit. The unit is named as a short story in a broader coverage, and also within one chain that has existed before, whether it is a short story, poem, novel, songs lyrics, science, philosophy until it reaches an unlimited point. This relationship is called intertextual.

\section{Conclusion}

From the description and analysis above, it shows that the "IWSBM" short story is clearly able to guide us to understand a few things, such as the oppositions found as a result of deconstructive reading, is: 1) Opposition between title and story;(2) Opposition between the story and the footnote; (3) Opposition between intuitive comprehension and logical reasoning;(4) opposition between fact and fiction; (5) opposition between "I lyric" and many people: and (6) opposition between the writer and the reader.

With many arguments of deconstructive approach to the "IWSBM" short story, then what appears as the binary opposition, has appeared from the deconstructive approach to the "IWSBM" can lead us to an understanding that there is no hierarchical opposition. This opposition is only an illusion, and only what appears, not more and not less, short story is a discourse, the result of construction. The short story is a text, text is known as a semantic meaning; we 
Hafsah:

The Short Story "I Want My Son to Become a Murderer" in Deconstructive Analysis

recognize one thing because of the difference.

Thus, the different, and the opposition that exists in this universe is not an eternal thing. As a message that can be drawn from this research is every bad thing will always return to who starts it as a boomerang.

\section{Acknowledgment}

The researcher would like to express the gratitude to the institution, Universitas Balikpapan, the Dean of Faculty of Letter, the Head of English Literature Department, the Research Institute and Community Service (Lembaga Penelitian dan Pengabdian Masyarakat) of Universitas Balikpapan, and alumnus of Faculty of Letters namely Indri Lestari, S.S. for helping the researcher completing this research.

\section{References}

Carter, D. (2006). Literary Theory: The Pocket Essential. Herts: Pocket Essentials.

Derrida, J. (1974). Of Grammatology. Baltimore: The John Hopkins, University Press.

Derrida, J. (1992). Acts of Literature. Derek Antride (Ed) New York. Routledge

Dunn, R. (1993). Pascamoderenisme: Populisme, Budaya Massa dan Garda Depan.

Prisma: Majalah Pemikiran Politik, Sosial dan Ekonomi, (1), 38-58.

Eagleton, T. (1983). Literary Theory. Oxford: Basil Blackwall.

Melani, B. (2002). Teori Sastra Sesudah Strukturalisme dari Studi Teks ke Studi Wacana

Budaya. Delivered at theory and literature critics workshop. Jakarta PPKB - LPUI.

Pujiharto, (2001). Analisis Dekonstruksi Cerpen Rembulan Terapung Di Kolam Renang.

Yogyakarta.

Sarup, M. (1993). An Introductory. Athens: The University of Georgia Press.

Teeuw, A. (1988). Sastra dan IImu Sastra. Jakarta: Pustaka Jaya Girimukti Pusaka.

Tyson, L. (2006). Critical Theory Today: A User-Friendly Guide. Routledge.

Whani, D. (1999). Aku Merindukan Anakku Menjadi Pembunuh in short story anthology AMAMP. Yogyakarta: Galang Press. 2003.

Yegen, C., \& Abukan, M. (2014). Derrida and Language: Deconstruction. International Journal of Linguistics, 6(2). Retrieved from

www.macrothink.org/journal/index.php/ij//article/download/5210/pdf_73 